\title{
On Masculine Culture in Pride and Prejudice
}

\author{
Xuejiao Zhu \\ School of Humanities and Education, Foshan University, Foshan, Guangdong, China
}

\begin{abstract}
This paper aspires to offer one more way of appreciating the all-time favorite Pride and Prejudice from Hofstede's viewpoint on masculine culture. Since culture is not static, this paper perceives that feminine contesting in quality of life, inner growth and sisterhood balances out masculine asserting in money issues, gentlemen education, and liberal humanism in Austen's time; and puts in perspective that any specific cultural phenomenon survives or disappears for a reason in conclusion.
\end{abstract}

Keywords: Masculine culture, Masculinity, Femininity.

\section{Introduction}

The academia has seen a huge number of articles on feminism or views on marriage in Jane Austen's works (the plethora does not degrade their scholarly significance). This paper, however, based on Hofstede's dimensions of cultural variability of masculinity versus femininity, takes another course into the masculine culture in Pride and Prejudice, the crown jewel unique with the world of two-inch wide ivory ${ }^{1}$ of its own.

According to Hofstede (1991), masculinity is a way to characterize cultures that value assertiveness, competitiveness, and material success; whereas femininity refers to cultural preferences for collaboration, nurturance, and harmony. The major differentiation between these two cultures is how gender roles are distributed in society. In masculine cultures, men and women are relatively well-matched in strength in that social gender roles are clearly distinct: men are supposed to be dominant outside, ambitious, and focus on the accumulation of wealth and social status, whereas women are supposed to be modest, tender and concerned with quality of life. In feminine cultures, however, social gender roles overlap in ways that no one should fight or be too tough and everyone should be concerned with maintaining good relationships with others and their living environment, among which Sweden and Norway are two typical examples. (Hofstede, 1991:140)

It is worth noting that masculine culture does not mean that masculinity gets every say so much so that femininity is suppressed or is nowhere to be found; rather, femininity contested in where masculinity asserted the most.

\section{Masculinity Asserted in ...}

\subsection{Money Issues}

Pride and Prejudice is a novel about economy and money issues are only one tip of the iceberg concerning masculine culture. Male achievement reinforces masculine dominance outside with the accumulation of wealth and social status, which presupposes women to take the tender roles to be dependent on men in order for a decent life.

\footnotetext{
1 Jane Austen once wrote with her characteristic modesty, "How could I join them (men, i.e., her contemporary male writers) on to the little bit (two inches wide) of ivory on which I work with so fine a brush, as produces little effect after much labour?",
}

[Colonel Fitzwilliam describing the situation of himself] "Younger sons cannot marry where they like... Our habits of expence make us too dependant, and there are not many in my rank of life who can afford to marry without some attention to money." (Austen 2002: 215)

Primogeniture is a widely adopted practice in Europe in Jane Austen's time. It is the right, by law or custom, of the firstborn male child to inherit the family estate, in preference to siblings. Colonel Fitzwilliam is very honest and straightforward in acknowledging his deplorable situation as the younger son in a wealthy family where the title or office has nothing to do with him and the only way to support himself is to climb the social ladder by marrying someone with a large sum of dowry.

"Mr. Bennet's property consisted almost entirely in an estate of two thousand a year, which, unfortunately for his daughters, was entailed in default of heirs male, on a distant relation; and their mother's fortune, though ample for her situation in life, could but ill supply the deficiency of his." (Austen 2002: 36)

In English common law, entail is a form of trust established by deed or settlement which restricts the sale or inheritance of an estate in real property and prevents the property from being sold, devised by will, or otherwise alienated by the tenant-in-possession, and instead causes it to pass automatically by operation of law to an heir pre-determined by the settlement deed. That is to say, as far as the Bennet family (no male offspring, five daughters though) concerns, none of the girls is entitled to inherit the landed estate or the income heavily dependent on the estate. It will all fall into the hands of a male heir (in this case, Mr. Collins) no matter how remotely related he is to the family. This basic norm about patriarchal society that a woman's happiness was mostly hinged upon the properties of the man she was to marry forces Mrs. Bennet to eagerly marry off her daughters for much-needed financial stability.

\subsection{Gentlemen Education}

Gentlemen tradition has always been running in the British blood, which once specifically refer to the descendants of ancient honorable families. Ever since the publication of John Locke's "Some Thoughts Concerning Education" in 1693, which puts forward the idea that the core of education should be physical, moral and intellectual; the definition of gentlemen has been broadened into an embodiment of graceful manners, personal integrity, great erudition, leisure 
activities, as well as noble pedigree. Masculine culture takes pride in its ability to nurture true gentlemen in society to assert male power and success.

"Mr. Bingley was good looking and gentlemanlike; he had a pleasant countenance, and easy, unaffected manners... His brother-in-law, Mr. Hurst, merely looked the gentleman; but his friend Mr. Darcy soon drew the attention of the room by his fine, tall person, handsome features, noble mien; and the report which was in general circulation within five minutes after his entrance, of his having ten thousand a year." (Austen 2002: 15)

This excerpt offers a clear concept of "a true gentleman". Strictly speaking, Bingley, whose father accumulated a lot of wealth, belongs to the new gentry class of the bourgeoisie in the 18th century, among which people with a large fortune managed to integrate into the upper class by purchasing real estate or marrying into the nobility. No wonder Bingley is only dubbed "gentlemanlike" by Austen and she is even more dismissive of his brother-in-law Mr. Hurst who "merely looked the gentleman". Things are different with Mr. Darcy whose mother's line is high and noble and father also a famous family though with no title, together with countless manors and dignified air, the traditional title of gentleman is perfectly justifiable for Darcy. Even the gentlemen present at the ball there "pronounced him to be a fine figure of a man" (Austen 2002: 15).

No one can be born to be a natural gentleman, not even biologically speaking. It is good upbringing combined with conscientious actions and constant self-reformation that gentility is finally externalized as the noble spirit of the upper class. The noble spirit can be traced back to chivalry which was originally the virtues of medieval knights. With the transformation from knights to gentry, chivalry developed into a gallant culture which emphasizes loyalty, courage, luxury, generosity and paying praise to ladies. It is expected that the knights or the gentry be excellent in battle, elegant in speech, and responsible in social affairs. The strong sense of mastership has been one with the blue blood ever since.

[Wickham speaking of Darcy] "It (pride) has often led him to be liberal and generous, - to give his money freely, to display hospitality, to assist his tenants, and relieve the poor. Family pride, and filial pride...have done this. Not to appear to disgrace his family, to degenerate from the popular qualities...is a powerful motive. He has also brotherly pride, which with some brotherly affection, makes him a very kind and careful guardian of his sister; and you will hear him generally cried up as the most attentive and best of brothers." (Austen 2002: 97)

The story unfolds that Darcy's pride has never been in the way of his gentlemanly nobility; if anything, he has every right to appear better than others. Admittedly, Wickham's intention of these words was to slander Darcy in front of Elizabeth; however, these words turn out to be the most objective and fair description of Darcy.

Besides, Darcy's being one true of a gentleman manifests itself in other minor details. He personally saw to it that Wickham's insurmountable debts were paid off and a respectable commission was purchased for him, and helped maintain Lydia a woman of character after her obnoxious elopement with the former, all from Darcy's purse of course. He could never "be prevailed on" to join in the censure of Elizabeth in spite of Miss Bingley's constant teasing witticisms on the former's "fine eyes". When Mrs. Hurst, taking the "disengaged" arm of Darcy, joined Miss Bingley and left Elizabeth alone, seeing the path just admitted three, he sensed their rudeness and immediately said, "This walk is not wide enough for our party. We had better go into the avenue.", which is either too intimately protective of Elizabeth or too impolitely inattentive to the other two. He is well-versed in piano, precise in fencing and has eclectic tastes in arts and literature. He is the living proof of "manners maketh man". He is the perfect specimen of delicate proprieties and good looks. In a word, Mr. Darcy speaks "fluent gentleman".

\subsection{Liberal Humanism}

The Renaissance gives rise to "man power", shifting focus on human - human feelings, human views, human actions, human rights. Liberalism arisen from the Enlightenment is a further development from humanism to lay more stress on individualism - freedom, tolerance, reason, equality and spirit of contract. Liberal humanism asks for emancipated and audacious pursuit of happiness in masculine culture because men and women are courageous enough to say NO to arranged marriages which aristocrats used as consolidation and ascendance for the family, which is in line with the Romanticism characterized by imagination, emotions, appreciation of external nature, and exaltation of the common man.

“...father (Mr. Bennet) captivated by youth and beauty, and that appearance of good humour, which youth and beauty generally give, had married a woman whose weak understanding and illiberal mind, had very early in their marriage put an end to all real affection for her (Mrs. Bennet). Respect, esteem, and confidence, had vanished for ever; and all his (Mr. Bennet) views of domestic happiness were overthrown." (Austen 2002: 274)

Masculine culture presupposes men to be the dominant figure and women the servant. An obvious characteristic required of a woman is a beautiful image which appears to be introverted and humble so that a man feel superior to her. This excerpt of a marriage serves as a lesson to warn of no guarantee of conjugal felicity without measurement of intelligence. Also, as for happiness, a man can only hope for entertainment resulting not from witticism but ignorance and folly; and end up fulfilling nuptial obligation and holding up decorum reprehensibly.

[Lady Catherine strongly disapproving of Darcy and Elizabeth] "...The upstart pretensions of a young woman (Elizabeth) without family, connections, or fortune... If you (Elizabeth) were sensible of your own good, you would not wish to quit the sphere, in which you have been brought up."

[Elizabeth] "In marrying your nephew (Darcy), I should not consider myself as quitting that sphere. He is a gentleman; I am a gentleman's daughter; so far we are equal." (Austen 2002: 407) 
[Darcy proposing] “...My affections and wishes are unchanged, but one word from you (Elizabeth) will silence me on this subject for ever."

...The happiness which this reply (Elizabeth said yes) produced, was such as he had probably never felt before; and he expressed himself on the occasion as sensibly and as warmly as a man violently in love can be supposed to do... (Austen 2002:418)

Thank Jane Austen for giving humankind not only a fairy tale but also an example of what a proper marriage should be. Masculine culture values genders' taking their own roles separately, which entails men and women being well-matched in strength and skill, if not physically speaking. Darcy broke through secular prejudice and obstruction of his aunt to marry Elizabeth, who is possessed of a sharp mind, sound judgement, and witty talk to meet with every urbane charm of the former. Darcy's obstinate proposal lands him a marriage of companionship measured between sense and sensibility, tinged with intelligence and emotions, and of course never short of "bread and butter", which has definitely caught the zeitgeist of subjective feelings yet improved with objective calmness.

\section{Femininity Contested in ...}

\subsection{Quality of Life}

Femininity makes itself heard in masculine culture by functioning organically with female care in feminine nurturance, a concern for good relationships and for quality of life.

[Charlotte Lucas speaking to Elizabeth] "I am not romantic you know. I never was. I ask only a comfortable home; and considering Mr. Collins's character, connections, and situation in life, I am convinced that my chance of happiness with him is as fair, as most people can boast on entering the marriage state." (Austen 2002: 149)

Charlotte is not a believer in romantic love or mutual affection; rather, she is a calm, pragmatic woman who consciously knows that the priority for her is to lead a financially secure life instead of having a husband she truly adores. In other words, she is a survivor and fighter in masculine culture in that she is both sensible enough to live with her own "inadequacy" (twenty-seven, plain-looking, parents' apprehension of her dying an old maid $)^{2}$ and mature enough to be thankful for an acceptable home and protection.

[Miss Bingley speaking of Miss Darcy, Darcy's little sister] "I never met with anybody who delighted me so much. Such a countenance, such manners! And so extremely accomplished for her age! Her performance on the pianoforté is exquisite."

[Mr. Bingley] ... "They all paint tables, cover skreens (screens) and net purses. I scarcely know any one who cannot do all this, and I am sure I never heard a young lady spoken of

\footnotetext{
2 The author of this paper, however, does not pass any judgement on any so-called rules about "what a woman should accomplish at a certain age" whatsoever.
}

for the first time, without being informed that she was very accomplished." (Austen 2002: 47)

This conversation reflects what to expect from a woman in masculine culture. Women are supposed to take up the gentle roles in domestic affairs to exert feminine nurturance, thus meaning they be thorough in music, drawing, modern languages and be expressive in manner of walking and tone of voice. They comprehend a great deal of accomplishments to surpass what is usually met with. Women power are demonstrated in that they work twice as hard to achieve half as far as what men do to deserve the seemingly descriptive saying "social genders have respective roles" in masculine culture.

\subsection{Inner Growth}

Young ladies embark on the exploration of self-discovery from courtship to matrimony to exert femininity in masculine culture. In Austen's time, marriage acts as the turning point for a girl who cannot receive higher education to enter society but can only go from father's house to husband's house, which necessitates appropriate handling of relationships and responsibilities; and this change causes growth. Literature world has no shortage of bildungsroman which discusses the moral and psychological growth of the protagonist; however, there is no denying fact that male characters often suffer inexorable hardship to "grow up", and yet female ones seem to mature overnight. In fact, women, like men, need to take in lots of books, lots of experiences, and go through confusion, pain, reflection to grow to maturity.

[Elizabeth's introspection] "How despicably have I acted!" she cried. - "I, who have prided myself on my discernment! - I, who have valued myself on my abilities! Who have often disdained the generous candour of my sister, and gratified my vanity, in useless or blameable distrust. - How humiliating is this discovery! - Yet, how just a humiliation! - Had I been in love, I could not have been more wretchedly blind. But vanity, not love, has been my folly. - Pleased with the preference of one (Wickham), and offended by the neglect of the other (Darcy), on the very beginning of our acquaintance, I have courted prepossession and ignorance, and driven reason away, where either were concerned. Till this moment, I never knew myself." (Austen 2002: 242)

Inner growth is more about the growth of self-consciousness, which is manifested as the process of a girl from passive acceptance of family and society, to reflection on familial and societal influences on herself, then to re-integration of outlook on life, and finally to independent determination of her behavior and attitude according to her new perspective. Elizabeth's examination is not limited to herself; rather, she realizes her mother's mean understanding, her father's sarcastic caprice and even her two less-developed under-educated sisters which inevitably exercise as injurious disadvantages to her and Jane (her elder sister). Yet most advantageously, Elizabeth's initial undue prejudice helps Darcy drop his pride in ways that the latter, who was taught good principles but was encouraged to be overbearing, examines himself along with the former; thus he was properly humbled and both learned to please the other half worthy of being pleased. A common man and a common woman, both 
ever sensible of the warmest gratitude to each other, united fabulously in their moral reformation and lived happily ever after.

\subsection{Sisterhood}

In Austen's time, domestically speaking, a typical "she" in masculine culture can only serve as a mother, wife or daughter, selflessly offering herself for the family, but neglecting her own value as a woman or the care, love and strength she can get from the other she's. Female literature, however, has been more often than not willing to construct a utopia of sisterhood acting as the spiritual and material combination which helps to condense scattered and vulnerable females into a collective force to guarantee their survival and development ever since. The motivation, undoubtedly, lies in female writers' or critics' striving for women's unity and equality to demand more than the role of a "trophy wife".

[Jane ill; Elizabeth going to her] "Elizabeth, feeling really anxious, was determined to go to her (Jane), though the carriage was not to be had; and as she was no horsewoman, walking was her only alternative. She declared her resolution." [mother declines] "... I do not wish to avoid the walk. The distance is nothing, when one has a motive;.." (Austen 2002: 40)

[Elizabeth telling Jane of Darcy's proposal] 'Miss Bennet's (Jane) astonishment was soon lessened by the strong sisterly partiality which made any admiration of Elizabeth (for Darcy) appear perfectly natural; and all surprise was shortly lost in other feelings." (Austen 2002: 260)

Austen made it clear and definite in her novels that having a good sister is one of the essential factors in women's prospects for a good life. She often fabricates a pair of sisters who is consciously not shaped into perfection but complements each other in character, temperament or perspective, which is embodied through the lively and straightforward Elizabeth and the gentle and quiet Jane in that the two heroines have to overcome obstacles coming both from masculine community and themselves respectively. The sisters share deep feelings, dependence, and the role of parents mutually due to a bright but secluded father and a stupid and vulgar mother. Pride and Prejudice interprets the touching sisterhood as such an indispensable part of their life that they often consult with each other to know themselves better, learn from each other to cope with worldly affairs, and grow together to become women of senses and wisdom. The harmonious ideal of reciprocal assistance and equality, which has always been there with them from childhood to womanhood, and which of course is something they cannot possibly get from a society of male dominance, will continue to function itself as a benevolent third party into their marriages to keep nurturing the two sisters when dealing with adverse surroundings. The positive sisterhood, therefore, is destined to not only compensate for the restrictions of social conventions laid upon their growth and education, but also add brilliance to their already-warranted marital bliss.

\section{Conclusion}

Hofstede's theory about masculinity versus femininity does not claim to be the one-for-all cultural pattern in that culture is no static institution; furthermore, there are bound to be many cultures and sub-cultures entangled in a society to make the world advance diversely and dynamically.

This paper helps to bring to light that "it is a truth universally acknowledged, that a single young lady in possession of a small fortune, must be in want of a wealthy husband" hidden behind Hofstede's definition of masculine culture; and yet the author of this paper does not put up any pretensions as to judge or evaluate the truth or the rationales in it. Any specific cultural phenomenon survived or disappeared for a reason in spite of all changes, thus guiding us to cherish what we have and win over what we could, but make peace with what we don't or can't, i.e., be reasonable and realistic. All in all, this paper hopes to provide one more way of thinking to appreciate the delicious caprice, magnetic rationality and profound wisdom in Jane Austen's works.

\section{References}

[1] Butler, Marilyn. Jane Austen and the War of Ideas. Oxford: Oxford UP, 1987.

[2] Hofstede, G. Cultures and Organisations: Software of the Mind. London: McGraw-Hill, 1991, 135-86.

[3] Hooks, B. Talking back: thinking feminist, thinking black. Boston: South End Press, 1989, p.20.

[4] Jane Austen: Pride and Prejudice. Penguin Classics. 2002.

[5] Knox-Shaw, Peter. Jane Austen and the Enlightenment. New York: Cambridge UP.2004.

[6] Locke, John. Some Thoughts Concerning Education. Ed. Ruth W. Grant and Nathan Tarcov. Indianapolis: Hackett, 1996.

[7] Fan Xiaohong. Austin's Love Utopia and Marriage Dystopia-Taking Sense and Sensibility and Pride and Prejudice as examples [J] Journal of Xi'an International Studies University, 2016, (1): 99-102.

[8] He Chang. "Emotionalism" or "Anti-emotionalism"? On the Image of Gentleman in Pride and Prejudice $[\mathrm{J}]$ Foreign literature, 2019 (06): 34-43.

[9] Yan Zhaoxiang. History of British Nobility [M] Beijing: People's Publishing House, 2000.

[10] Zhao Xuemei. Probing into the Palmy Days of Britain's Gentleman Culture from Pride and Prejudice [J] Journal of Central South University (Social Science Edition), 2013, 19(01): 228-233.

[11] Zhu Hong. Austin Research [C] Beijing: China Federation of Literary and Art Publishing Company, 1985.

[12] Online dictionary.https://useenglishwords.com/entail/ item 13 [Accessed: June. 12, 2021]

\section{Author Profile}

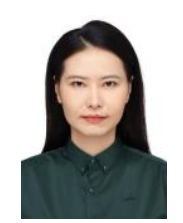

Xuejiao Zhu received the Bachelor of Arts degree in English language and Literature from Industrial and Commercial College, which is affiliated to Hebei University, Baoding, and is studying for 
the Master degree in English Education in Foshan University, Foshan, China now. She is also currently working with the view of the Ph.D. degree in Language Education. Her research interests include English language and Literature, English Education for ESL learners, and Washback studies. 